\title{
Population Dynamics in Italian Canids between the Late Pleistocene and Bronze Age
}

\author{
Kyriaki Koupadi ${ }^{1,2,+}$, Francesco Fontani ${ }^{2,+}{ }^{(D)}$, Marta Maria Ciucani ${ }^{3}$ (D) Elena Maini ${ }^{4}$ (D), \\ Sara De Fanti ${ }^{5,6}$, Maurizio Cattani ${ }^{7}$, Antonio Curci ${ }^{4}\left(\mathbb{D}\right.$, Gabriele Nenzioni $^{8}$, Paolo Reggiani ${ }^{9}$, \\ Adam J. Andrews ${ }^{2,5}$, Stefania Sarno ${ }^{5}$, Carla Bini ${ }^{10}\left(\mathbb{D}\right.$, Susi Pelotti ${ }^{10}\left(\mathbb{D}\right.$, Romolo Caniglia ${ }^{11}$, \\ Donata Luiselli ${ }^{2, \ddagger(D)}$ and Elisabetta Cilli $2, *, \ddagger$ (D)
}

1 Hellenic Ministry of Culture and Sports, Ephorate of Antiquities of the City of Athens, Makriyianni 2-4, 11742 Athens, Greece; koupadikrk@gmail.com

2 Department of Cultural Heritage, University of Bologna, Via Degli Ariani 1, 48121 Ravenna, Italy; francesco.fontani@studio.unibo.it (F.F.); a.andrews@unibo.it (A.J.A.); donata.luiselli@unibo.it (D.L.)

3 Section for Evolutionary Genomics, the GLOBE Institute, University of Copenhagen, Oester Voldgade 5-7, 1350 Copenhagen, Denmark; martamariaciucani@gmail.com

4 ArcheoLaBio-Research Centre for Bioarchaeology, Department of History and Cultures, University of Bologna, Via San Vitale 30, 48121 Ravenna, Italy; elena.maini@unibo.it (E.M.); antonio.curci@unibo.it (A.C.)

5 Department of Biological Geological and Environmental Sciences, University of Bologna, Via Selmi 3, 40126 Bologna, Italy; sara.defanti2@unibo.it (S.D.F.); stefania.sarno2@unibo.it (S.S.)

6 Interdepartmental Centre "Alma Mater Research Institute on Global Challenges and Climate Change (Alma Climate)", University of Bologna, Via Petroni 26, 40126 Bologna, Italy

7 Department of History and Cultures, University of Bologna, Via San Vitale 30, 48121 Ravenna, Italy; maurizio.cattani@unibo.it

8 Museo della Preistoria “Luigi Donini”, Via Fratelli Canova 49, 40068 San Lazzaro di Savena, BO, Italy; gabriele.nenzioni@comune.sanlazzaro.bo.it

9 Paleostudy, Via Martiri delle Foibe 1, 35028 Piove di Sacco, PD, Italy; paleostudy@libero.it

10 Department of Medical and Surgical Sciences, University of Bologna, Via Irnerio 49, 40126 Bologna, Italy; carla.bini@unibo.it (C.B.); susi.pelotti@unibo.it (S.P.)

11 Unit for Conservation Genetics (BIO-CGE), Italian Institute for Environmental Protection and Research (ISPRA), Via Ca' Fornacetta 9, 40064 Ozzano dell’Emilia, BO, Italy; romolo.caniglia@isprambiente.it

* Correspondence: elisabetta.cilli@unibo.it

+ These authors equally contributed to the article.

$\ddagger$ Denotes co-senior authorship.

Received: 30 October 2020; Accepted: 23 November 2020; Published: 26 November 2020

\begin{abstract}
Dog domestication is still largely unresolved due to time-gaps in the sampling of regions. Ancient Italian canids are particularly understudied, currently represented by only a few specimens. In the present study, we sampled 27 canid remains from Northern Italy dated between the Late Pleistocene and Bronze Age to assess their genetic variability, and thus add context to dog domestication dynamics. They were targeted at four DNA fragments of the hypervariable region 1 of mitochondrial DNA. A total of 11 samples had good DNA preservation and were used for phylogenetic analyses. The dog samples were assigned to dog haplogroups A, C and D, and a Late Pleistocene wolf was set into wolf haplogroup 2. We present our data in the landscape of ancient and modern dog genetic variability, with a particular focus on the ancient Italian samples published thus far. Our results suggest there is high genetic variability within ancient Italian canids, where close relationships were evident between both a 24,700 years old Italian canid, and Iberian and Bulgarian ancient dogs. These findings emphasize that disentangling dog domestication dynamics benefits from the analysis of specimens from Southern European regions.
\end{abstract}


Keywords: ancient DNA; dogs; domestication; mitochondrial DNA; population genetics; archaeology; Italy

\section{Introduction}

Domestication processes involving plants and animals have had a strong biological and cultural impact on humans. Dog domestication in particular is one of the most fascinating and unresolved processes. Our special bond with "man's best friend" traces back its roots to the Late Pleistocene [1]. Thus, dogs were the first species domesticated, originating from an unknown population of grey wolves [2-5], and predated the appearance of agriculture in the archeological record by several thousand years [2].

The origin of dogs dates to the ancient coevolution and mutualism established between Paleolithic humans and wolves [3,6-8]. However, details such as the time and place of dog domestication, the motivation behind this process, and how it occurred are yet to be clarified $[2,6,9,10]$. Uncertainty regarding dog domestication is mainly due to a lack of available data, and those obtained by key morphological characters that were not fixed during the initial phases of the domestication process. Disentangling dog genetics is complicated due to: (i) the occurrence of several population bottlenecks in ancient wolves, most notably 20,000 years ago [11], along with the megafauna "crisis" during the Last Glacial Maximum (LGM), and because of human persecution towards wolves in the last 200 years, which dramatically reduced their genetic variability [12,13]; (ii) the explosive radiation of dog breeds in the 19th century, with more than 400 officially recognized breeds today; and (iii) recurrent post-divergence dog-to-wolf gene flow events. The combination of these factors makes the phylogeographic history of wolves and dogs difficult to reconstruct based on either archaeological data or contemporary genetic patterns from wolves and dogs. Here, ancient DNA offers utility towards reconstructing past genetic variability, and the tracking of evolutionary patterns and population dynamics through time.

Archaeological and morphological records of ancient canid remains from France, Germany (BonnOberkassel) and Spain indicate that the first confidently identified domesticated dogs originated by at least 15,000 or 13,500 years ago [14-20]. In comparison, East Asia returned its earliest archaeological dog remains dated to 12,500 years ago [2]. Some studies highlighted Paleolithic dogs dated between 40,000 and 16,000 before present (BP) from Goyet Cave, Belgium [21], Russia [22-25], Germany [26] and the Czech Republic $[27,28]$, but the taxonomy of these proposed Paleolithic dogs is still contentious. Paleogenomic analysis is yet to unambiguously solve this debate as the mitogenomes of the ancient Paleolithic dogs analyzed by Thalmann et al. [29] constitute an ancient sister group to all modern dogs and wolves.

Recent advances in DNA sequencing technologies and protocols on ancient biological remains have enabled the production of data at unprecedented resolution. Paleogenomic studies attested a long-term and close history of dogs alongside humans during the Paleolithic $[5,9,10]$, supporting predictions based on the genome of a 35,000-year-old wolf Taimyr fossil [30]. In particular, Bergstrom and colleagues [5] detected a deep diversification of dogs at the onset of the Holocene, with the presence of at least five dog ancestry lineages 11,000 years ago, testifying a deep genomic history of dogs during the Paleolithic. By comparing ancient human and dog datasets, they also inferred dispersal patterns, showing interesting concordance (Levant-related ancestry in Africa and early agricultural Europe) or discrepancy (steppe pastoralist expansion in Eurasia) between population dynamics of these two species during time and space [5]. The genomic data suggest a single [5,10] or dual [9] origin of domestic dogs. However, the acquisition of a broader set of ancient samples is required to further clarify the details of the dog domestication process.

Especially in Europe, there is a limited availability of data on the genetic diversity of wolves prior to their domestication and their contribution to the genomic diversity of dogs $[11,13,31-33]$. In addition, 
genetic data on early dogs is lacking for most areas of Europe [9,10], particularly in the southern regions. To this end, the Italian peninsula, due to its crucial geographic position as important glacial refugium during the LGM (circa 24,000-18,000 years BP), is particularly interesting in the study of speciation, population dynamics and migration during this relevant period in the dog domestication timeline.

Few ancient Italian canid samples have been genetically analyzed at present, and these were predominantly wolves $[12,13,31,34,35]$. A recent study showed the presence of a haplotype belonging to the dog haplogroup $(\mathrm{Hg}) \mathrm{A}$ in two canids from Italy dated between 24,700 and $~ 20,000$ years BP [13]. Those results, combined with the findings of Pires et al. [33] on the occurrence of Late Pleistocene wolves and Mesolithic dog carrying a $\mathrm{Hg}$ A canine haplotype in another glacial refugium, the Iberian Peninsula, stimulate interest towards these areas and their role in the dog domestication issue as a whole. Neolithic Bulgarian dogs in the Balkan Peninsula [6] with high percentages of $\mathrm{Hg} \mathrm{A}$ and B support the findings of Pires et al. [33]. These results are of particular interest because, according to previous data [36], Hg A-dogs were only estimated to have arrived in Europe during the Bronze Age. Therefore, this reiterates the need to broaden investigations to these areas.

In this study, we provide a preliminary overview of the ancient Italian mitochondrial DNA (mtDNA) variability of dogs belonging to a large temporal transect, spanning from the Late Pleistocene to the Bronze Age. We collected ancient specimens from Northern Italy, which were analyzed at a portion of the hypervariable region 1 (HVR-1) of the mitochondrial DNA, which is highly informative for wolf and dog phylogenetics. We contextualized the data alongside a comprehensive panel of ancient and modern dogs and wolves. In particular, this study aims to: (1) investigate the genetic variability of ancient Italian dogs; and (2) improve the data about dog haplogroups dynamics in Southern Europe, especially regarding $\mathrm{Hg} \mathrm{A}$.

\section{Materials and Methods}

\subsection{Sample Selection}

We collected 27 specimens (Table 1, Figure S1 and Table S1) from different archaeological sites and rescue excavations in Italy (Figure 1). Sampling was mainly focused on Northeast Italy, where it was possible to recover specimens spanning a large timeframe $(25,000-3100$ years $B P)$. The majority of samples were found in excavation layers that were estimated to belong to the Bronze Age, except from three sites. These were: a phalanx (CAF18.0066) from Cava a Filo, dated at 24,400 years BP, a tooth (NIP10) from Celletta dei Passeri, in Forlì, dated to the Chalcolithic period, and four specimens (IPC1, IPC6, IPC7, IPC8) from Riccione, dated to the Chalcolithic to Bronze Age transition. Further details about the archaeological sites are available in File S1. Information about samples can be retrieved from Table 1 and Table S1.

Table 1. Recovery location, dating and morphological identification of the selected samples.

\begin{tabular}{cccc}
\hline Sample & Archaeological Site & Dating (Years BP) $^{\mathbf{1}}$ & Species \\
\hline CAF18.0066 * & Cava a Filo, Bologna & $25,005-23,842$ & Wolf \\
\hline ORD1 & & $3600-3280$ & Dog \\
ORD2 & $3600-3280$ & Dog \\
ORD3 & & $3600-3280$ & Dog \\
ORD6 & & $3600-3120$ & Dog \\
ORD7 & & $3600-3120$ & Dog \\
ORD8 & Via Ordiere, Solarolo & $3600-3280$ & Dog \\
ORD9 & & $3600-3280$ & Dog \\
ORD13 & & $3600-3280$ & Dog \\
ORD14 & & $3580-3380$ & Dog \\
ORD15 & & $3600-3280$ & Dog \\
ORD16 & & $3600-3280$ & Dog \\
ORD20 & & $3600-3280$ & Dog \\
\hline
\end{tabular}


Table 1. Cont

\begin{tabular}{cccc}
\hline Sample & Archaeological Site & Dating (Years BP) $^{\mathbf{1}}$ & Species \\
\hline NIP10 & Celletta dei Passeri, Forlì & $5350-4250$ & Dog \\
\hline FA1 & & $3400-3120$ & Dog \\
FA5 & & $3290-3120$ & Dog \\
FA7 & & $3290-3120$ & Dog \\
FA8 & Foro Annonario, Cesena & $3290-3120$ & Dog \\
FA9 & & $3290-3120$ & Dog \\
FA10 & & $3290-3120$ & Dog \\
\hline IPC1 ${ }^{*}$ & & $4750-3600$ & Dog \\
IPC6 & Ipercoop, Riccione & $4750-3600$ & Dog \\
IPC7 & & $4750-3600$ & Dog \\
IPC8 & & $4750-3600$ & Dog \\
\hline CVGS2 & & $4250-3600$ & Dog \\
CVGS3 & Centro VGS, Cattolica & $4250-3600$ & Wolf \\
CVGS6 & & $4250-3600$ & Dog \\
\hline
\end{tabular}

${ }^{1}$ All samples were dated through a relative chronology except for CAF18.0066, whose dating is a result of accelerator mass spectrometry (AMS) dating of other samples from the same stratigraphic unit (S.U.). The conversion of the relative dating from $\mathrm{BC}$ to $\mathrm{BP}$ was done by the addition of 1950 years. ${ }^{*}$ Highlights the samples for which PCR amplifications were successful.

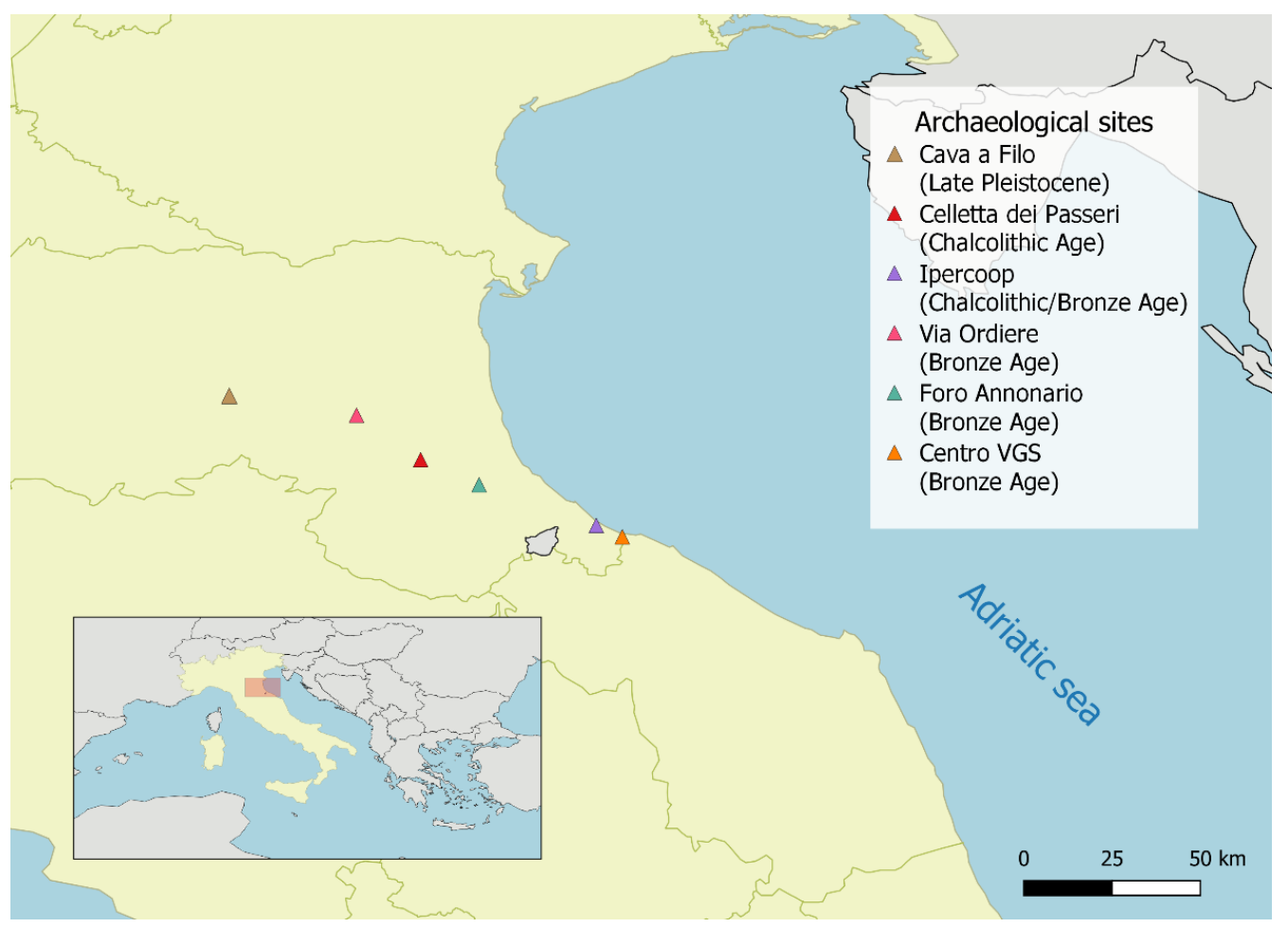

Figure 1. Map of the archaeological excavation locations from which the selected specimens were collected. Map created using QGIS [35].

Despite that this study was mainly focused on the genetic origin and dynamics of dogs in Italy, two samples identified as wolf (CVGS3 and CAF18.0066) were added to genetically characterize the former population of wolves, and because previous findings highlighted interesting results about Late Pleistocene dog haplogroup dynamics in this area [13].

Samples were selected by taking into consideration the stratigraphic unit where they were found, the type, and the preservation state of the remains available. Due to the occurrence of mixed or incomplete remains, we selected specimens from different stratigraphic units to improve the likelihood of studying different individuals. We preferentially selected skeletal elements which allow for a better endogenous DNA preservation, such as the petrous bones [37,38] and teeth, especially those preserved inside the alveolus and thus less prone to contamination [39,40]. 


\subsection{Experimental Procedure}

Genetic analysis took place in the ancient DNA laboratory (aDNALab) of the University of Bologna, in Ravenna, exclusively dedicated to the treatment of ancient DNA following high sterility standards. Post-PCR procedures took place in a separate laboratory. Strict ancient DNA authenticity criteria were followed during the analyses [41-44]. The aDNALab is organized in separate rooms, each dedicated to different experimental procedures (sampling, DNA extraction and amplification sample set up). All materials and instruments used were DNA free and sterilized before use using bleach and/or UV light, depending on their composition. Negative controls were prepared alongside samples to confirm the absence of exogenous DNA and investigate the presence of intra-laboratory contamination.

The specimens were photographed and then decontaminated, i.e., they were exposed to UV light $(\sim 250 \mathrm{~nm})$ and their surface was mechanically cleaned before sampling. The majority of samples extracted were obtained in powder, by means of a dental drill with sterile drill bits or diamond cutting discs, using different approaches based on the type of specimen. Teeth were either drilled directly from the root or carefully ground after the separation of the root from the crown. In some cases, in which this separation was not feasible, the whole tooth was pulverized. Samples CAF18.0066, NIP10, IPC6, IPC7 and IPC8 were processed in pieces [45]. All samples were extracted and amplified twice to confirm the data.

\subsection{DNA Isolation}

A two-day extraction protocol, slightly modified from those in the literature $[45,46]$, was followed. The samples were extracted in groups of four or five to avoid inter-contamination, using a maximum of $300 \mathrm{mg}$ of material. Samples CAF18.0066, NIP10, IPC6, IPC7 and IPC8 underwent a pre-extraction step to minimize the presence of any exogenous DNA in the sample extracts [45]. This step included a partial digestion in $3 \mathrm{~mL}$ extraction buffer (0.45 M EDTA, $0.25 \mathrm{mg} / \mathrm{mL}$ Proteinase K) for $20 \mathrm{~min}$ at $37^{\circ} \mathrm{C}$ under constant rotation. Samples were then centrifuged, and the pre-digest supernatants were removed. At this point, all samples underwent the same extraction protocol, by adding another $3 \mathrm{~mL}$ extraction buffer. The samples were incubated overnight under constant rotation at $37^{\circ} \mathrm{C}$. Binding and subsequent phases were performed using the MinElute PCR Purification Kit (Qiagen, Hilden, Germany) and reservoirs, as suggested by Dabney et al. [46]. DNA was eluted in $50 \mu \mathrm{L}$ of TET buffer (10 mM Tris-HCl, 1 mM EDTA, 0.05\% Tween-20).

\subsection{DNA Amplification and Sequencing}

Extracts were amplified using polymerase chain reaction (PCR). Four different pairs of primers were used, targeting the hypervariable region 1 (HVR-1) of the mitochondrial genome. Due to the highly fragmented and fragile nature of ancient DNA, three overlapping amplicons were targeted using three sets of primers previously tested by Ersmark and colleagues, to obtain a $360 \mathrm{bp}$ fragment [47]. The first fragment fell between positions 15,411-15,558 (MS_wolf1 and dogdl5, length 148 bp), the second between 15,481-15,684 (MS_Wolf2F and MS_Wolf2R, length $205 \mathrm{bp}$ ) and the third between 15,602-15,812 (MS_Wolf3F and MS_Wolf3R, length 211 bp). Since several specimens failed to amplify due to degradation, primers targeting a short fragment (length $99 \mathrm{bp}, 57 \mathrm{bp}$ without primers), located between 15,588-15,687 (HVR1-wolf-F and -R), were used [48]. The 57 bp fragment, despite its limited size, includes 30 polymorphic sites that represent the majority of the informative nucleotide positions of the mtDNA control region, already tested for phylogenetic purposes in several studies concerning ancient canids [21,32,47,48].

All PCR reactions contained 5-10 ng DNA extract in a total reaction volume of $25 \mu \mathrm{L}$. The thermal cycler was set at $94{ }^{\circ} \mathrm{C}$ for denaturation, and $72{ }^{\circ} \mathrm{C}$ for elongation for all reactions. We used three different temperatures for annealing depending on the couples of primers used ( $55^{\circ} \mathrm{C}$ for fragment 1 , $53{ }^{\circ} \mathrm{C}$ for fragments 2 and 3 and $50{ }^{\circ} \mathrm{C}$ for the short fragment). The number of cycles varied between 40 and 50. Amplification success was determined by gel electrophoresis. 
Prior to sequencing, samples were purified using ExoSAP PCR Product Cleanup Reagent (ThermoFisher, Waltham, MA, USA), following the manufacturer's instructions.

The sequencing reactions were prepared in the Laboratory of Molecular Anthropology \& Centre for Genome Biology of the Department of Biological, Geological and Environmental Sciences (BiGeA, Bologna, Italy), using the BigDye Terminator v1.1 Cycle Sequencing Kit (Thermo Fisher Scientific, Waltham, MA, USA). PCR products were separated through CE using a POP1 polymer on SeqStudio Genetic Analyzer (Applied Biosystems, Foster City, CA, USA) and analyzed by the Sequencing Analysis Software v.7 (Applied Biosystems) in the Forensic Genetics Laboratory of the University of Bologna. The samples were sequenced in both directions.

Sequences are available on GenBank (www.ncbi.nlm.nih.gov/genbank; accession numbers: MW092060-MW092070, see Table S1).

\subsection{Haplotype Identification and Phylogenetic Analyses}

Electropherograms were analyzed and edited using the software FinchTV (Geospiza Inc., Seattle, WA, USA) and BioEdit $[49,50]$. Sequences were aligned using the dog mtDNA sequences NC_002008 and EU789787 as reference, following the steps of previously published papers $[6,9,51,52]$. Haplogroup assignments were determined through a phylogenetic analysis by creating UPGMA trees in MEGA X (Penn State University, PA, USA) [53], using reference samples with well-defined dog matrilines, available from previous studies $[54,55]$. The haplogroup of the ancient samples analyzed was also tested through the MitoToolPy program [56], with reference sequence EU789787 [57].

In order to investigate haplogroup patterns and dynamics, ggplot2 [58], a data visualization package in R [59], was used to create a graphical representation of the proportions of haplogroup through time. The plot included the ancient Eurasian dogs from this study and those available in the literature $[6,9,10,13,29,31,33,34,52,60-64]$ (Table S1).

With the aim to reconstruct the ancient genetic variability of our samples and the Italian specimens sequenced so far [13,31], these sequences were checked against the GenBank database [65]. Thus, we included PIC1, PIC2, PIC3, PIC4 and PIC5 samples from Verginelli et al. [31] and also OWW4 and OWW9 samples from Ciucani et al. [13]. We added Italian samples from previous studies because recently, several papers were published about Late Pleistocene ancient wolves [66], historical sledge dogs [67], ancient wolves and dogs from Iberia [33] and ancient Bulgarian dogs [6].

A database of published mtDNA sequences (Table S1) was constructed to set the data produced herein in the wider context of ancient and modern samples. The ancient database used contains ancient samples ranging from the Late Pleistocene to Late Antiquity, published by previous studies $[6,9,13,29,31,33,34,36,52,57,62-64,68-76]$. In particular, two alignments of different lengths, $57 \mathrm{bp}$ and $360 \mathrm{bp}$, were prepared to match the lengths of the sequences obtained herein, and those Italian canid remains previously analyzed $[13,31,34]$. These alignments contain 1731 and 134 sequences, respectively.

Collapsing of the sequences into haplotypes was done using the software DnaSP v.5.10.01 [77]. The shortest alignment ( $57 \mathrm{bp}$ ) was used to build a Median Joining network $(\varepsilon=0)$ through the Network software $[78,79]$.

A Bayesian phylogenetic tree was constructed with the software MrBayes v. 3.2 [80] using the $360 \mathrm{bp}$ alignment (Table S1) and a coyote sequence (Canis latrans, GenBank acc. no.: DQ480509) as outgroup. The tree was generated using the best fitting evolutionary model GTR $+\mathrm{I}+\gamma, 10,000,000$ Markov Chain Monte Carlo (MCMC) generations, with a 10\% burn-in, sampling at each 1000th interval. The $\alpha$ parameter was 0.801 and the proportion of invariable sites was 0.602 . Potential scale reduction factors, and effective sample size parameters were interpreted as output to confirm MCMC convergence [80].

\section{Results}

Out of 27 selected specimens, 11 samples (Tables 1 and 2) were successfully amplified and complied with the selected authentication criteria (i.e., the results were confirmed by multiple 
extractions and amplifications, see also the "Experimental Procedure" subsection). The materials used and the guidelines followed during the experiments provide confidence on the authenticity of the DNA fragments retrieved. The absence of amplified fragments in the negative controls, and the length and preservation of the obtained sequences validated our methodology to prevent and detect contamination. The successful samples belonged to the archaeological sites of Cava a Filo, Ipercoop Riccione, via Ordiere Solarolo, and Foro Annonario Cesena.

\subsection{Haplotype Variability}

The 11 sequences were assigned to seven different haplotypes. One sequence (CAF18.0066) was assigned to the wolf haplogroup 2, based on the subdivision of two main and distinct wolf mitochondrial haplogroups (known as $\mathrm{Hg} 1$ and $\mathrm{Hg}$ 2) proposed by Pilot et al. [32]. The remaining sequences were assigned to the established dogs haplogroups A-D [54,68] though MitoToolPy, whose results were confirmed by their positions in the two phylogenetic trees (Figures S2 and S3). Among the 10 dog haplotypes, five sequences were assigned to $\operatorname{dog}$ haplogroup $\mathrm{A}$, four to $\operatorname{dog}$ haplogroup $\mathrm{C}$ and one to haplogroup D (Table 2). The Table S1 provides an overview of the variants of the samples here analyzed, with respect to the reference (EU789787).

An analysis on the occurrence of dog haplogroups in ancient Eurasian canids (Figure 2 and Table S1) attested the presence of $\mathrm{Hg} \mathrm{A}$ in canids dated $>15,000 \mathrm{BP}$ from Italy and the appearance of $\mathrm{Hg} \mathrm{D}$ at around $\sim 8000 \mathrm{BP}$.

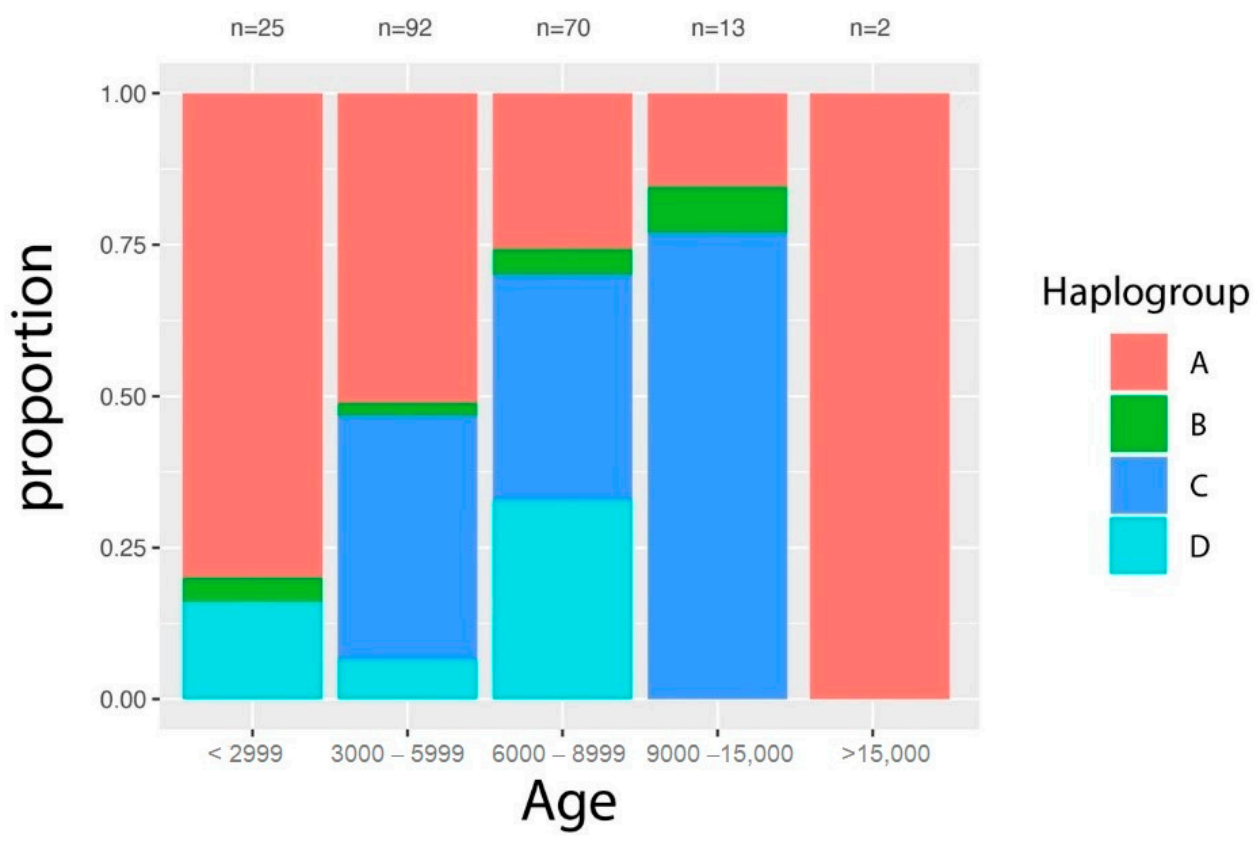

Figure 2. Frequency of the four main mtDNA haplogroups (A-D) in Eurasia in different time periods. The $\mathrm{X}$ axis represents the age (BP), while the fill values represent the haplogroups abundance. The most recent dogs here considered are from Late Antiquity (Table S1).

The seven haplotypes obtained were checked against the GenBank database, along with sequences from other ancient Italian specimens, which corresponded to seven haplotypes [13,31]. We found that 9 out of 14 haplotypes from ancient Italian specimens matched published samples in the GenBank database (Table 2). In particular, starting from the Late Pleistocene, the sample OWW9, for which Ciucani and colleagues [13] previously detected a match with modern dogs $(n=93)$, also matches ancient interesting specimens. Indeed, the same haplotype was retrieved from a Bulgarian Chalcolithic dog [6] and two historical sledge dogs from the North American Arctic [67]. The other Italian canid (OWW4), which shared the same 57 bp fragment with the sample OWW9, matched with a Mesolithic dog, two Chalcolithic dogs from Bulgaria and Iberia [6,33] and the most recent dogs (Roman dogs 
from Iberia and historical sledge dogs from North American Arctic) [67,81]. The sample CAF18.0066 matched only with six Late Pleistocene wolves, of which five were from the same site [13] and one from Belgium [48].

In the Late Glacial period, the sample PIC1 showed the occurrence of the haplogroup C, in agreement with the results of coeval ancient dog specimens from Central Europe (Germany-Switzerland) [29] and Italy [34]. PIC1 and the subsequent early Holocene PIC2 specimen showed no similarity with any samples reported in the literature. Moreover, the PIC2 sample attested the presence of haplogroup B in Italy in the early Holocene. These two samples, along with the PIC3 specimen were not confidently assigned to either proto-dogs or wolves, using both morphological and genetic analyses [31]. PIC3 shared the haplotype of one Neolithic Bulgarian dog and four historical sledge dogs from North American Arctic, in addition to more than a hundred modern dogs.

In the Chalcolithic and Bronze Age, our samples were assigned to haplogroups C, D (in the sole IPC6 sample) and A. Four samples (IPC1, IPC8, IPC6 and FA8) matched no other sequences in the GenBank database. Moreover, PIC4 and ORD7 matched only modern dog samples, and in particular ORD7 matched with a modern Bulgarian Hound dog [82].

Table 2. Matches of ancient Italian samples sequences against the GenBank database.

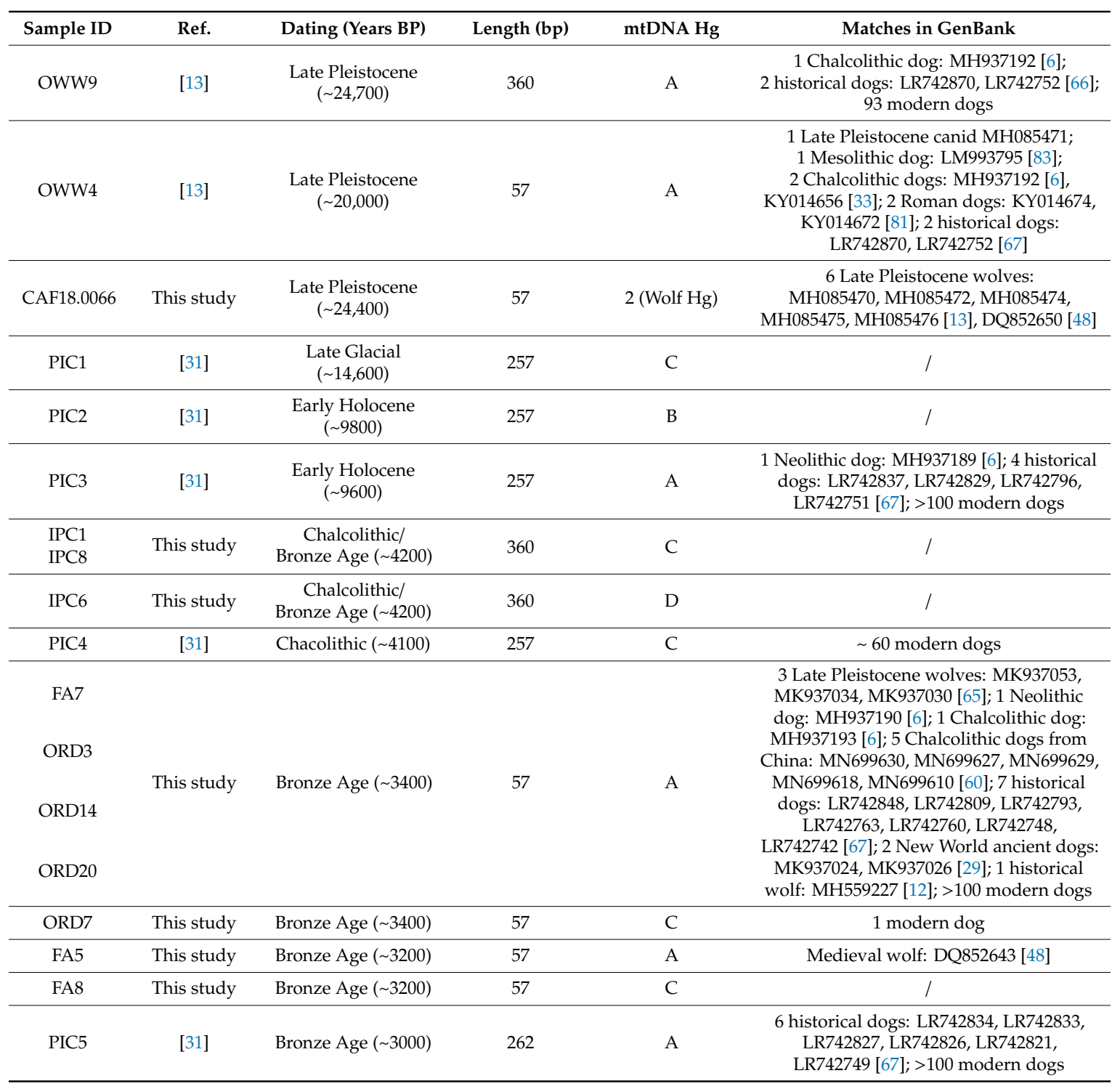


Four Bronze Age samples from Solarolo and Cesena (ORD3, ORD14, ORD20 and FA7) showed similarity with Late Pleistocene wolves and modern dogs. Lastly, FA5 and PIC5 matched with recent samples: a Medieval wolf, and historical and modern dogs, respectively (Table 2).

\subsection{Phylogenetic Analyses}

The network (Figure 3) clearly distinguished the four main dog haplogroups (A, B, C and D), despite its construction using the short alignment $(57 \mathrm{bp})$. The ancient Italian samples presented high levels of genetic variability, being scattered across the whole network.

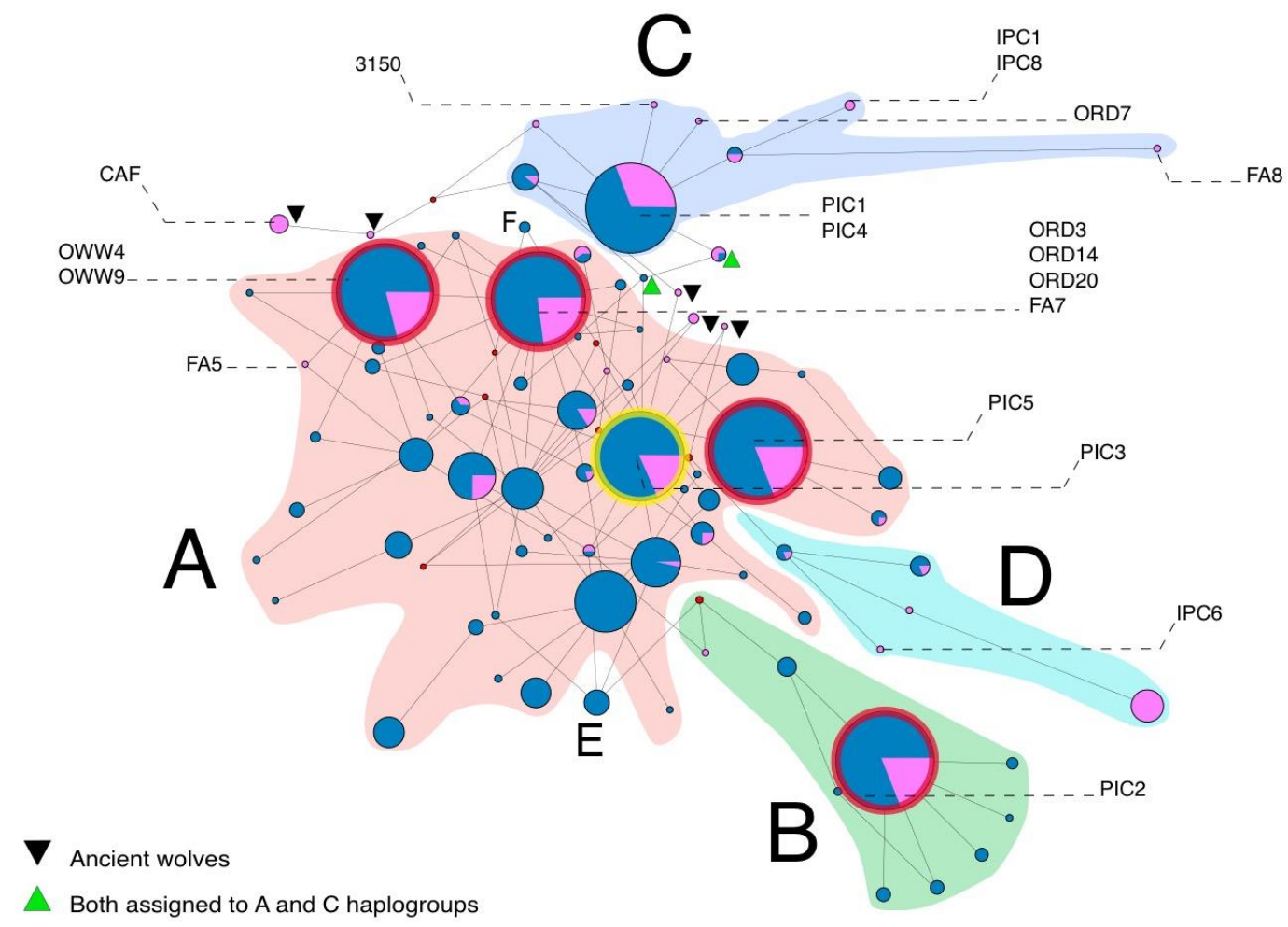

Figure 3. Median Joining network based on the short fragment (57 bp) alignment containing ancient and modern dogs and ancient Italian wolves. European samples are shown in purple, Asian samples in blue. The red rings highlight haplotypes that contain both ancient Italian and Bulgarian samples (alongside modern samples); the yellow ring highlights a haplotype that contains, among others, ancient Italian, Iberian and Bulgarian samples. The four main canine haplogroups are highlighted in pink $(\mathrm{Hg} \mathrm{A})$, green $(\mathrm{Hg} \mathrm{B})$, purple $(\mathrm{Hg} \mathrm{C})$ and light blue $(\mathrm{Hg} \mathrm{D})$. Minor haplogroups $\mathrm{E}$ and F contain only modern individuals. Red dots represent median vectors. Samples included in the network are listed in the Table S1.

Within $\mathrm{Hg}$ A, five samples (ORD3, ORD14, ORD20, FA5 and FA7) are placed only one mutational step away from the two samples of the same haplogroup, OWW4 and OWW9, which were dated, respectively, at $\sim 24,700$ and $\sim 20,000$ years BP and were recovered from the site of Cava a Filo [13]. A connection is evident between the samples ORD3, ORD14, ORD20 and FA7 and the Italian sample PIC3 from Romanelli Cave published by Verginelli et al. [31], situated one mutational step away.

It is interesting to note the proximity of the ancient Iberian samples sequenced by Pires et al. [33], LYEP44 ( 14,000 BP), and the Mesolithic ones (LYEP3, LYEP68B, LYEP74, LYEP75), which fall in the same 57 bp haplotype of the Late Glacial sample PIC3 [31].

Almost all of the ancient Bulgarian specimens published by Yankova et al. [6] shared haplotypes with ancient Italian samples. In fact, among the samples from Bulgaria, the Neolithic and Chalcolithic samples (Ohod19, Urdo14 and Bal16), and a Late Antiquity sample (KpAn15), shared the same $57 \mathrm{bp}$ haplotype with PIC5. Conversely, a Chalcolithic sample (OkGl10) fell in the same haplotype of OWW9. 
Two Neolithic samples (MPGra13 and ToPro1) were associated with PIC3, and some Chalcolithic samples (ToPro7 and SulPo9) were associated with ORD3, ORD14, ORD20 and FA7.

The samples belonging to $\mathrm{Hg} \mathrm{C}$ tell a slightly different story. The Italian samples PIC1 and PIC4 share the same haplotype in particular with a Newgrange sample dated at $4800 \mathrm{BP}$ [8] and a dog from Germany dated at 12,500 BP [29]. As mentioned previously, ORD7 shared the same haplotype with a modern sample, a Bulgarian Hound dog, and it is one mutational step away from ancient Italian PIC1 and PIC4 samples. Moreover, a Late Glacial Italian dog from Boschin et al. [34] is also situated one mutational step away from PIC1 and PIC4 samples.

For haplogroup B, we highlighted the proximity of some Neolithic and Chalcolithic Bulgarian samples (Slat11, Burg22 and Doln8), which belonged from the same haplotype of PIC2.

The Bayesian tree (Figure 4) shows a well resolved mitochondrial phylogeny with a good support of the branches, despite being built from a limited mitochondrial fragment (360 bp). The dogs fall within the main four clades (A-D) and the topology of the tree is similar to those who include large portions of the mitogenome (e.g., [34]). The samples studied herein fell in different canine clades. IPC1 and IPC8 were situated closer to the sister groups constituted by modern dogs belonging to $\mathrm{Hg} C$, near the Neolithic samples CTC and HXH [10] and the dog dated at 12,500 BP [29], all retrieved in Germany. The GenBank acc. n. MK937022 and MK937037 refer to canids from the Kesserloch cave in Switzerland dated at, respectively, $\sim 11,700$ and $\sim 14,100$ BP [66]. The first immediately branches off the $\operatorname{dog} \mathrm{Hg} \mathrm{C}$ and the second falls inside the variability of this haplogroup. The specimen MK937040 is a canid from Predmosti in the Czech Republic, dated at 2900 BP [27,66]. Additionally, the sample highlighted as the first dog specimen from Italy [34] could probably not be correctly placed in this tree as in the one made by the authors considering the whole mitogenome because of the presence of several unassigned bases $(\mathrm{N})$ for this sample in the $360 \mathrm{bp}$ region here considered. Moreover, the Italian sample IPC6 branches off immediately before the clade of the modern dogs of the Hg D. Interestingly, the Late Pleistocene sample OWW9 was placed inside the branch of many modern dog breeds with Hg A, along with two Bulgarian ancient dogs (GenBank acc. n. MH937189 and MH937192) dated, respectively, to the Neolithic and the Chalcolithic age [6] and some New World dogs. 


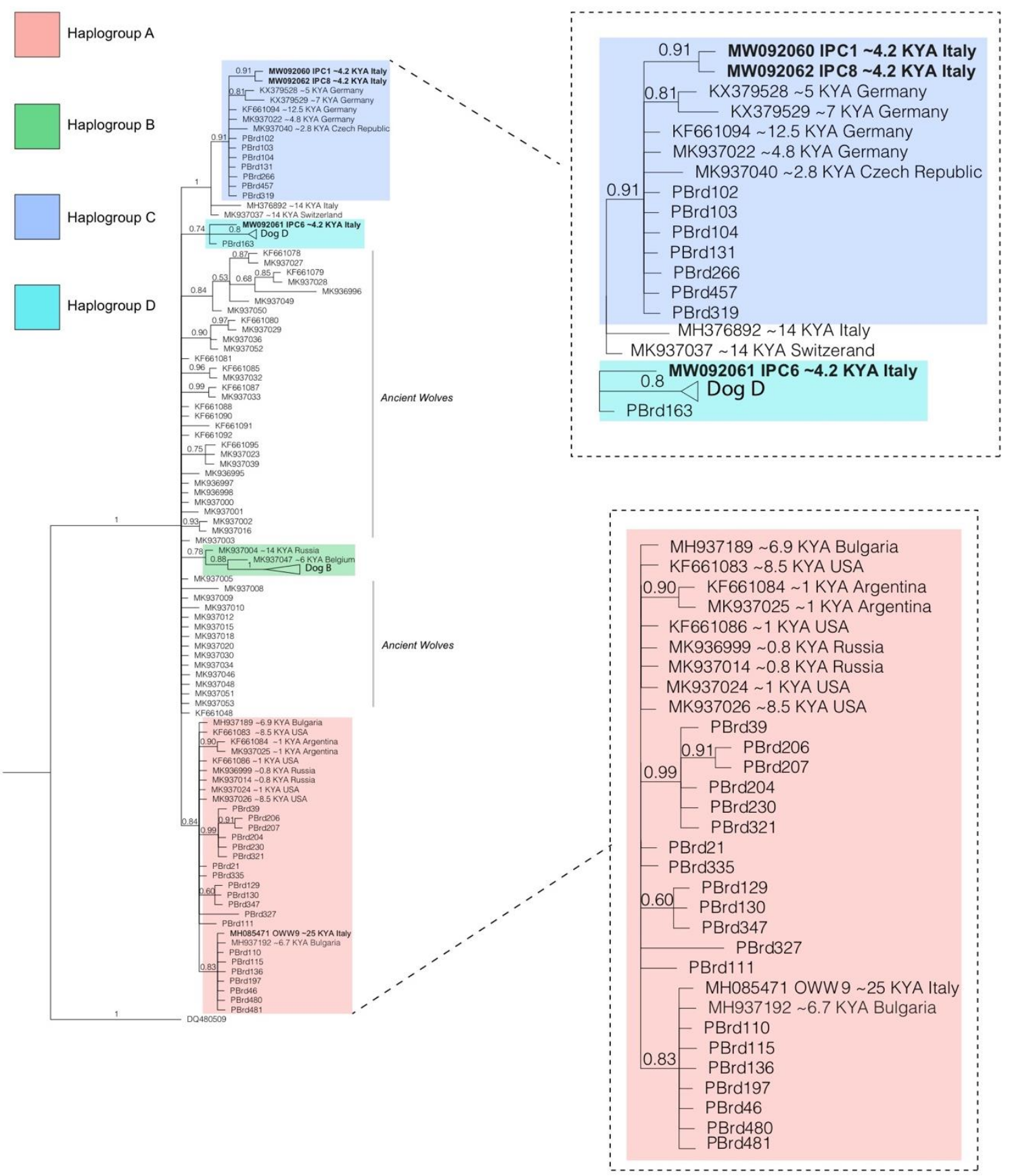

Figure 4. Bayesian tree of ancient and modern dogs and wolves based on the $360 \mathrm{bp}$ database of mtDNA (Table S1). Samples from this study are highlighted in bold. Ancient canid specimens in the three enlargements are labeled with the respective country of origin and their approximate reported age. Monophyletic clusters of modern canid sequences are collapsed and identified by the dog clade to which they belong. PBrd denotes modern dog samples available from literature. The outgroup (a coyote) is not shown. Samples included in the tree are listed in the Table S1.

\section{Discussion}

As highlighted in previous studies, the analysis of southern [13,31,33] and southeastern [6] European canids is vital to our understanding of dog migration, admixture and replacements in the context of domestication. This is particularly relevant as the three glacial refugia, the Italian, Iberian and Balkan peninsulas, may have played an important role in the first population dynamics of ancient dogs. 
Few ancient Italian canid samples have been genetically analyzed thus far, and they are mainly composed of wolves [12,13,31,34,35]. To date, only three studies, represented by four samples unambiguously morphologically and genetically attributable to dogs, attempted to investigate the genetic variability of ancient dogs from the Italian Peninsula [5,31,34].

With this study, we have enhanced the understanding of the mitochondrial variability of ancient dogs in Italy. Despite the limited number of samples analyzed herein, this research provided a preliminary overview of the population patterns and variability in ancient Italian dogs. In particular, this study was focused on the period between $\sim 24,700$ and $\sim 3000$ years BP, in an area where previous findings highlighted the presence of Late Pleistocene canids carrying dog $\mathrm{Hg} \mathrm{A}$ [13].

Dogs are conventionally grouped in four main clades (A-D) [54,68]. Frantz et al. [9] highlighted that, based on the available data, ancient European dogs belonged to $\mathrm{Hg} C$ or D, with the $\mathrm{Hg} C$ as the most frequently observed haplogroup in Europe prior to the Neolithic. However, most modern European dogs belong to $\mathrm{Hg} \mathrm{A}$ and $\mathrm{Hg}$ B. Frantz et al. [9] suggested that their findings were due to a partial replacement by East Asian dogs, instead of the result of genetic drift alone. According to Ollivier and colleagues [36], the first haplogroup present in Europe prior to the Neolithic was haplogroup C, while haplogroups A and D are thought to have arrived in Europe during Neolithic and post-Neolithic migrations alongside humans, i.e., from the Near East for $\mathrm{Hg} \mathrm{D}$, and successive Pontic steppe migrations during the Bronze Age for $\mathrm{Hg} \mathrm{A} \mathrm{[36].} \mathrm{Recently,} \mathrm{thanks} \mathrm{to} \mathrm{the} \mathrm{analysis} \mathrm{of} 27$ new ancient dog genomes, Bergstrom et al. [5] detected the presence of $\mathrm{Hg} \mathrm{A}$ in a Mesolithic Karelian dog from northern Russia (dated at 10,930 years BP), and in a Neolithic Croatian sample (dated at $\sim 4500$ years BP). They also found that a single Neolithic $\mathrm{Hg}$ A dog from a Megalithic site in Sweden, dated at 5000 BP, can be modeled as a single-source proxy for 90 to $100 \%$ of the ancestry of most European dogs [5].

Through our phylogenetic analysis, we evidenced a great degree of variability between 11 ancient Italian samples, where samples were grouped in seven different haplotypes of the haplogroups A, $\mathrm{C}$ and D. Only a single sample (CAF18.0066), likely a wolf, fell within the wolf $\mathrm{Hg} 2$ and matched with six Late Pleistocene wolves, of which five were from the same site [13], and one was from Belgium [48]. It is important to note that the Late Pleistocene Italian samples included in the analyses (OWW9, OWW4 and CAF18.0066) have not yet been morphometrically analyzed; thus, no conclusion can be drawn about their possible placement as Paleolithic dogs.

Despite that the first dog populations in Europe were perceived to belong to haplogroup C [36], the presence of a 24,700-year-old Hg A specimen (OWW9) from Italy triggered the need to further investigate European domestication origins [13]. According to the network analysis, five of the samples from this study (FA5, FA7, ORD3, ORD14 and ORD20) appear to be related to OWW9, as they are positioned only one mutational step away from it. This further supports the early presence of $\mathrm{Hg} \mathrm{A}$ in Europe.

It is worthy to note the diachronic genetic continuity of the peculiar haplotype carried by the Late Pleistocene OWW9 specimen, as highlighted by the matches in the GenBank database. The same haplotype was present in a Chalcolithic dog from Bulgaria [6], in two historical sledge dogs from the North American Arctic [67], and in 100 modern dogs (Table 2 and Figure 3).

Our data suggest that there are close relationships between Italian, Iberian [33] and Bulgarian ancient specimens [6]. Several samples shared the same haplotype or were placed few mutational steps from the Italian samples studied herein. Moreover, most of these dated from the Late Pleistocene to the Bronze Age, belong to the $\mathrm{Hg}$ A. This sheds light on the history of this lineage, on the population dynamics of dogs in these areas, and in the broad context of dog domestication.

The current study, although based on a limited number of samples and focused on a small portion of the mtDNA genome, highlights the importance of ancient Italian samples to the understanding of past population dynamics and mtDNA variability in dogs. However, since mtDNA has a limited resolution, particularly in this case since a limited fragment was amplified, future studies will certainly benefit from the application of next-generation sequencing (NGS) technologies to analyze entire mitoor nuclear-genomes of ancient canids. 


\section{Conclusions}

Our results on the close proximity between Italian samples and those from the Iberian [33] and the Balkan [6] Peninsulas, combined with the evidence published by Pires and colleagues [33], which suggested the possibility of a pre-Neolithic local domestication processes from Iberian wolves, suggest that these areas are of particular interest for domestication dynamics. The acquisition of a broader set of ancient samples from these areas, including ancient representatives from the Late Pleistocene period, is required to further clarify the details of dog domestication and evolution. We highlight that any study that intends to analyze ancient dogs for the analysis of domestication will certainly have to be based on all available evidence from archaeology, morphology and genetics.

Supplementary Materials: The following are available online at http://www.mdpi.com/2073-4425/11/12/1409/s1, File S1: Information about the archaeological contexts, Figure S1: Pictures of the specimens from which the samples were collected, Figure S2: UPGMA Tree based on the alignment at $57 \mathrm{bp}$ with Italian samples in bold, and reference specimens with well-defined dog matrilines, Figure S3: UPGMA Tree based on the alignment at 360 bp with Italian samples in bold, and reference specimens with well-defined dog matrilines, Table S1: List of the samples here analyzed and the modern and ancient specimens available in the literature, utilized for the network and the Bayesian phylogenetic tree, along with the data from ancient Eurasian dogs used for the graphical representation of past haplogroups distribution in Figure 2. This table also includes the mtDNA variants of the specimens here analyzed with respect to the dog reference used.

Author Contributions: E.C., E.M., R.C. and D.L. conceived the study; E.M., A.C., M.C., G.N. and P.R. provided and collected the samples; E.C. designed the experiments; K.K., F.F., S.D.F. and C.B. performed the experiments; K.K., F.F., M.M.C., A.J.A. and S.S. analyzed the data; D.L. and S.P. provided the research funds; K.K., F.F. and E.C. wrote the original draft. All authors have read and agreed to the published version of the manuscript.

Funding: This work was supported by an RFO grant (University of Bologna) assigned to D.L.

Acknowledgments: We are grateful to Monica Miari from the Soprintendenza Archeologia, Belle Arti e Paesaggio per la città metropolitana di Bologna e le province di Modena, Ferrara e Reggio Emilia, and also to the Soprintendenza Archeologia, Belle Arti e Paesaggio per le provincie di Ravenna, Forli-Cesena e Rimini, who allowed us to study the samples. We would also like to thank Sara Silvestrini, who assisted during the experimental procedures, and colleagues Florencia Debandi, Dalia Gasparini and Erika Valli for their archaeological support.

Conflicts of Interest: The authors declare no conflict of interest.

\section{References}

1. Morey, D.F.; Jeger, R. From wolf to dog: Late Pleistocene ecological dynamics, altered trophic strategies, and shifting human perceptions. Hist. Biol. 2017, 29, 895-903. [CrossRef]

2. Larson, G.; Karlsson, E.K.; Perri, A.; Webster, M.T.; Ho, S.Y.; Peters, J.; Stahl, P.W.; Piper, P.J.; Lingaas, F.; Fredholm, M. Rethinking dog domestication by integrating genetics, archeology, and biogeography. Proc. Natl. Acad. Sci. USA 2012, 109, 8878-8883. [CrossRef] [PubMed]

3. Lallensack, R. Ancient Genomes Heat up Dog Domestication Debate: Nature News \& Comment. Available online: https://www.nature.com/news/ancient-genomes-heat-up-dog-domestication-debate-1.22320 (accessed on 5 February 2019).

4. Freedman, A.H.; Gronau, I.; Schweizer, R.M.; Ortega-Del Vecchyo, D.; Han, E.; Silva, P.M.; Galaverni, M.; Fan, Z.; Marx, P.; Lorente-Galdos, B.; et al. Genome Sequencing Highlights the Dynamic Early History of Dogs. PLoS Genet. 2014, 10, e1004016. [CrossRef] [PubMed]

5. Bergström, A.; Frantz, L.; Schmidt, R.; Ersmark, E.; Lebrasseur, O.; Girdland-Flink, L.; Lin, A.T.; Storå, J.; Sjögren, K.-G.; Anthony, D.; et al. Origins and genetic legacy of prehistoric dogs. Science 2020, 370, 557. [CrossRef]

6. Yankova, I.; Marinov, M.; Neov, B.; Petrova, M.; Spassov, N.; Hristov, P.; Radoslavov, G. Evidence for Early European Neolithic Dog Dispersal: New Data on Southeastern European Subfossil Dogs from the Prehistoric and Antiquity Ages. Genes 2019, 10, 757. [CrossRef] [PubMed]

7. Pierotti, R.; Fogg, B.R. The First Domestication: How Wolves and Humans Coevolved; Yale University Press: New Haven, CT, USA, 2017.

8. Wang, G.; Zhai, W.; Yang, H.; Fan, R.; Cao, X.; Zhong, L.; Wang, L.; Liu, F.; Wu, H.; Cheng, L. The genomics of selection in dogs and the parallel evolution between dogs and humans. Nat. Commun. 2013, 4, 1860. [CrossRef] 
9. Frantz, L.A.; Mullin, V.E.; Pionnier-Capitan, M.; Lebrasseur, O.; Ollivier, M.; Perri, A.; Linderholm, A.; Mattiangeli, V.; Teasdale, M.D.; Dimopoulos, E.A. Genomic and archaeological evidence suggest a dual origin of domestic dogs. Science 2016, 352, 1228-1231. [CrossRef]

10. Botigué, L.R.; Song, S.; Scheu, A.; Gopalan, S.; Pendleton, A.L.; Oetjens, M.; Taravella, A.M.; Seregély, T.; Zeeb-Lanz, A.; Arbogast, R.-M. Ancient European dog genomes reveal continuity since the Early Neolithic. Nat. Commun. 2017, 8, 16082. [CrossRef]

11. Fan, Z.; Silva, P.; Gronau, I.; Wang, S.; Armero, A.S.; Schweizer, R.M.; Ramirez, O.; Pollinger, J.; Galaverni, M.; Del-Vecchyo, D.O. Worldwide patterns of genomic variation and admixture in gray wolves. Genome Res. 2016, 26, 163-173. [CrossRef]

12. Dufresnes, C.; Miquel, C.; Remollino, N.; Biollaz, F.; Salamin, N.; Taberlet, P.; Fumagalli, L. Howling from the Past: Historical Phylogeography and Diversity Losses in European Grey Wolves. Proc. R. Soc. B 2018, 285, 20181148. [CrossRef]

13. Ciucani, M.M.; Palumbo, D.; Galaverni, M.; Serventi, P.; Fabbri, E.; Ravegnini, G.; Angelini, S.; Maini, E.; Persico, D.; Caniglia, R.; et al. Old wild wolves: Ancient DNA survey unveils population dynamics in Late Pleistocene and Holocene Italian remains. PeerJ 2019, 7, e6424. [CrossRef] [PubMed]

14. Pionnier-Capitan, M.; Bemilli, C.; Bodu, P.; Célérier, G.; Ferrié, J.-G.; Fosse, P.; Garcià, M.; Vigne, J.-D. New Evidence for Upper Paleolithic Small Domestic Dogs in South-Western Europe. J. Archaeol. Sci. 2011, 38, 2123-2140. [CrossRef]

15. Morey, D.F. In search of Paleolithic dogs: A quest with mixed results. J. Archaeol. Sci. 2014, 52, 300-307. [CrossRef]

16. Boudadi-Maligne, M.; Mallye, J.-B.; Langlais, M.; Barshay-Szmidt, C. Magdalenian dog remains from Le Morin rock-shelter (Gironde, France). Socio-economic implications of a zootechnical innovation. Revue D'archéologie Préhistorique 2012, 39-54. [CrossRef]

17. Vigne, J.-D. L’humérus de chien magdalénien de Erralla (Gipuzkoa, Espagne) et la domestication tardiglaciaire du loup en Europe. Munibe 2005, 51, 279-287.

18. Benecke, N. Studies on early dog remains from Northern Europe. J. Archaeol. Sci. 1987, 14, 31-49. [CrossRef]

19. Street, M. Ein Wiedersehen mit dem Hund von Bonn-Oberkassel. In Festschrift für Günter Nobis; Bonner Zoologische Beiträge: Bonn, Germany, 2002; pp. 269-290.

20. Street, M.; Napierala, H.; Janssens, L. The late Palaeolithic dog from Bonn-Oberkassel in context. In The Late Glacial Burial from Oberkassel Revisited; Giemsch, L., Schmitz, R.W., Eds.; Rheinische Ausgrabungen; Verlag Philipp Von Zabern: Darmstadt, Germany, 2015.

21. Germonpré, M.; Sablin, M.V.; Stevens, R.E.; Hedges, R.E.M.; Hofreiter, M.; Stiller, M.; Després, V.R. Fossil dogs and wolves from Palaeolithic sites in Belgium, the Ukraine and Russia: Osteometry, ancient DNA and stable isotopes. J. Archaeol. Sci. 2009, 36, 473-490. [CrossRef]

22. Ovodov, N.D.; Crockford, S.J.; Kuzmin, Y.V.; Higham, T.F.G.; Hodgins, G.W.L.; van der Plicht, J. A 33,000-Year-Old Incipient Dog from the Altai Mountains of Siberia: Evidence of the Earliest Domestication Disrupted by the Last Glacial Maximum. PLoS ONE 2011, 6, e22821. [CrossRef]

23. Germonpré, M.; Sablin, M.V.; Lázničková-Galetová, M.; Després, V.; Stevens, R.E.; Stiller, M.; Hofreiter, M. Palaeolithic dogs and Pleistocene wolves revisited: A reply to Morey (2014). J. Archaeol. Sci. 2015, 54, 210-216. [CrossRef]

24. Germonpré, M.; Fedorov, S.; Danilov, P.; Galeta, P.; Jimenez, E.-L.; Sablin, M.; Losey, R.J. Palaeolithic and prehistoric dogs and Pleistocene wolves from Yakutia: Identification of isolated skulls. J. Archaeol. Sci. 2017, 78, 1-19. [CrossRef]

25. Sablin, M.V.; Khlopachev, G.A. The Earliest Ice Age Dogs: Evidence from Eliseevichi 1. Curr. Anthropol. 2002, 43, 795-799. [CrossRef]

26. Camarós, E.; Münzel, S.C.; Cueto, M.; Rivals, F.; Conard, N.J. The evolution of Paleolithic hominin-carnivore interaction written in teeth: Stories from the Swabian Jura (Germany). J. Archaeol. Sci. Rep. 2016, 6, 798-809. [CrossRef]

27. Germonpré, M.; Lázničková-Galetová, M.; Losey, R.J.; Räikkönen, J.; Sablin, M.V. Large canids at the Gravettian Předmostí site, the Czech Republic: The mandible. Quat. Int. 2015, 359-360, 261-279. [CrossRef]

28. Germonpré, M.; Lázničková-Galetová, M.; Sablin, M.V. Palaeolithic dog skulls at the Gravettian Předmostí site, the Czech Republic. J. Archaeol. Sci. 2012, 39, 184-202. [CrossRef] 
29. Thalmann, O.; Shapiro, B.; Cui, P.; Schuenemann, V.J.; Sawyer, S.K.; Greenfield, D.; Germonpré, M.B.; Sablin, M.V.; López-Giráldez, F.; Domingo-Roura, X. Complete mitochondrial genomes of ancient canids suggest a European origin of domestic dogs. Science 2013, 342, 871-874. [CrossRef]

30. Skoglund, P.; Ersmark, E.; Palkopoulou, E.; Dalén, L. Ancient wolf genome reveals an early divergence of domestic dog ancestors and admixture into high-latitude breeds. Curr. Biol. 2015, 25, 1515-1519. [CrossRef]

31. Verginelli, F.; Capelli, C.; Coia, V.; Musiani, M.; Falchetti, M.; Ottini, L.; Palmirotta, R.; Tagliacozzo, A.; De Grossi Mazzorin, I.; Mariani-Costantini, R. Mitochondrial DNA from Prehistoric Canids Highlights Relationships Between Dogs and South-East European Wolves. Mol. Biol. Evol. 2005, 22, 2541-2551. [CrossRef]

32. Pilot, M.; Branicki, W.; Jedrzejewski, W.; Goszczyński, J.; Jedrzejewska, B.; Dykyy, I.; Shkvyrya, M.; Tsingarska, E. Phylogeographic history of grey wolves in Europe. BMC Evol. Biol. 2010, 10, 104. [CrossRef]

33. Pires, A.E.; Detry, C.; Chikhi, L.; Rasteiro, R.; Amorim, I.R.; Simões, F.; Matos, J.; Petrucci-Fonseca, F.; Ollivier, M.; Hänni, C.; et al. The curious case of the Mesolithic Iberian dogs: An archaeogenetic study. J. Archaeol. Sci. 2019, 105, 116-129. [CrossRef]

34. Boschin, F.; Bernardini, F.; Pilli, E.; Vai, S.; Zanolli, C.; Tagliacozzo, A.; Fico, R.; Fedi, M.; Corny, J.; Dreossi, D.; et al. The first evidence for Late Pleistocene dogs in Italy. Sci. Rep. 2020, 10, 13313. [CrossRef]

35. Angelici, F.M.; Ciucani, M.M.; Angelini, S.; Annesi, F.; Caniglia, R.; Castiglia, R.; Fabbri, E.; Galaverni, M.; Palumbo, D.; Ravegnini, G.; et al. The Sicilian Wolf: Genetic Identity of a Recently Extinct Insular Population. Zool. Sci. 2019, 36, 189-197. [CrossRef] [PubMed]

36. Ollivier, M.; Tresset, A.; Frantz, L.A.; Bréhard, S.; Bălăşescu, A.; Mashkour, M.; Boroneanţ, A.; Pionnier-Capitan, M.; Lebrasseur, O.; Arbogast, R.-M. Dogs accompanied humans during the Neolithic expansion into Europe. Biol. Lett. 2018, 14, 20180286. [CrossRef] [PubMed]

37. Pinhasi, R.; Fernandes, D.; Sirak, K.; Novak, M.; Connell, S.; Alpaslan-Roodenberg, S.; Gerritsen, F.; Moiseyev, V.; Gromov, A.; Raczky, P.; et al. Optimal Ancient DNA Yields from the Inner Ear Part of the Human Petrous Bone. PLoS ONE 2015, 10, e0129102. [CrossRef] [PubMed]

38. Gamba, C.; Jones, E.R.; Teasdale, M.D.; McLaughlin, R.L.; Gonzalez-Fortes, G.; Mattiangeli, V.; Domboróczki, L.; Kővári, I.; Pap, I.; Anders, A.; et al. Genome flux and stasis in a five millennium transect of European prehistory. Nat. Commun. 2014, 5. [CrossRef] [PubMed]

39. Higgins, D.; Austin, J.J. Teeth as a source of DNA for forensic identification of human remains: A Review. Sci. Justice 2013, 53, 433-441. [CrossRef]

40. Pilipenko, A.S.; Molodin, V.I. Paleogenetic analysis in archeological studies. Russ. J. Genet. Appl. Res. 2011, 1, 51-72. [CrossRef]

41. Fulton, T.L. Setting up an ancient DNA laboratory. Methods Mol. Biol. 2012, 840, 1-11.

42. Gilbert, M.T.P.; Bandelt, H.-J.; Hofreiter, M.; Barnes, I. Assessing ancient DNA studies. Trends Ecol. Evol. 2005, 20, 541-544. [CrossRef]

43. Cooper, A.; Poinar, H.N. Ancient DNA: Do it right or not at all. Science 2000, 289, 1139. [CrossRef]

44. Llamas, B.; Valverde, G.; Fehren-Schmitz, L.; Weyrich, L.S.; Cooper, A.; Haak, W. From the field to the laboratory: Controlling DNA contamination in human ancient DNA research in the high-throughput sequencing era. STAR Sci. Technol. Archaeol. Res. 2017, 3, 1-14. [CrossRef]

45. Damgaard, P.B.; Margaryan, A.; Schroeder, H.; Orlando, L.; Willerslev, E.; Allentoft, M.E. Improving access to endogenous DNA in ancient bones and teeth. Sci. Rep. 2015, 5, 11184. [CrossRef] [PubMed]

46. Dabney, J.; Knapp, M.; Glocke, I.; Gansauge, M.-T.; Weihmann, A.; Nickel, B.; Valdiosera, C.; García, N.; Pääbo, S.; Arsuaga, J.-L. Complete mitochondrial genome sequence of a Middle Pleistocene cave bear reconstructed from ultrashort DNA fragments. Proc. Natl. Acad. Sci. USA 2013, 110, 15758-15763. [CrossRef] [PubMed]

47. Ersmark, E.; Klütsch, C.F.C.; Chan, Y.L.; Sinding, M.-H.S.; Fain, S.R.; Illarionova, N.A.; Oskarsson, M.; Uhlén, M.; Zhang, Y.; Dalén, L.; et al. From the Past to the Present: Wolf Phylogeography and Demographic History Based on the Mitochondrial Control Region. Front. Ecol. Evol. 2016, 4, 134. [CrossRef]

48. Stiller, M.; Green, R.E.; Ronan, M.; Simons, J.F.; Du, L.; He, W.; Egholm, M.; Rothberg, J.; Keates, S.; Ovodov, N. Patterns of nucleotide misincorporations during enzymatic amplification and direct large-scale sequencing of ancient DNA. Proc. Natl. Acad. Sci. USA 2006, 103, 13578-13584. [CrossRef] [PubMed]

49. FinchTV. Available online: http://geospiza.com (accessed on 25 October 2020).

50. Hall, T. BioEdit: A user-friendly biological sequence alignment editor and analysis program for Windows 95/98/NT. Nucleic Acids Symp. Ser. 1999, 41, 95-98. 
51. Kim, K.S.; Lee, S.E.; Jeong, H.W.; Ha, J.H. The complete nucleotide sequence of the domestic dog (Canis familiaris) mitochondrial genome. Mol. Phylogenet. Evol. 1998, 10, 210-220. [CrossRef]

52. Deguilloux, M.F.; Moquel, J.; Pemonge, M.H.; Colombeau, G. Ancient DNA supports lineage replacement in European dog gene pool: Insight into Neolithic southeast France. J. Archaeol. Sci. 2009, 36, 513-519. [CrossRef]

53. Tamura, K.; Dudley, J.; Kumar, S. Molecular Evolutionary Genetics Analysis (MEGA) Software Version 4.0. Mol. Biol. Evol. 2007, 23, 1596-1599. [CrossRef]

54. Duleba, A.; Skonieczna, K.; Bogdanowicz, W.; Malyarchuk, B.; Grzybowski, T. Complete mitochondrial genome database and standardized classification system for Canis lupus familiaris. Forensic Sci. Int. Genet. 2015, 19, 123-129. [CrossRef]

55. Song, J.-J.; Wang, W.-Z.; Otecko, N.O.; Peng, M.-S.; Zhang, Y.-P. Reconciling the conflicts between mitochondrial DNA haplogroup trees of Canis lupus. Forensic Sci. Int. Genet. 2016, 23, 83-85. [CrossRef]

56. Peng, M.-S.; Fan, L.; Shi, N.-N.; Ning, T.; Yao, Y.-G.; Murphy, R.W.; Wang, W.-Z.; Zhang, Y.-P. DomeTree: A canonical toolkit for mitochondrial DNA analyses in domesticated animals. Mol. Ecol. Resour. 2015, 15, 1238-1242. [CrossRef] [PubMed]

57. Pang, J.-F.; Kluetsch, C.; Zou, X.-J.; Zhang, A.; Luo, L.-Y.; Angleby, H.; Ardalan, A.; Ekström, C.; Sköllermo, A.; Lundeberg, J. mtDNA data indicate a single origin for dogs south of Yangtze River, less than 16,300 years ago, from numerous wolves. Mol. Biol. Evol. 2009, 26, 2849-2864. [CrossRef] [PubMed]

58. Wickham, H. Ggplot2: Elegant Graphics for Data Analysis; Springer: New York, NY, USA, 2016.

59. R Core Team. R: A Language and Environment for Statistical Computing; R Foundation for Statistical Computing: Viena, Austria, 2020.

60. Zhang, M.; Sun, G.; Ren, L.; Yuan, H.; Dong, G.; Zhang, L.; Liu, F.; Cao, P.; Ko, A.M.-S.; Yang, M.A.; et al. Ancient DNA Evidence from China Reveals the Expansion of Pacific Dogs. Mol. Biol. Evol. 2020, 37, 1462-1469. [CrossRef] [PubMed]

61. Pionnier-Capitan, M. La Domestication du Chien en Eurasie: Étude de la Diversité Passée, Approches Ostéoarchéologiques, Morphométriques et Paléogénétiques. Ph.D. Thesis, École Normale Superiéure, Paris, France, 2010.

62. Malmström, H.; Storå, J.; Dalén, L.; Holmlund, G.; Götherström, A. Extensive Human DNA Contamination in Extracts from Ancient Dog Bones and Teeth. Mol. Biol. Evol. 2005, 22, 2040-2047. [CrossRef]

63. Malmström, H.; Svensson, E.M.; Gilbert, M.T.P.; Willerslev, E.; Götherström, A.; Holmlund, G. More on Contamination: The Use of Asymmetric Molecular Behavior to Identify Authentic Ancient Human DNA. Mol. Biol. Evol. 2007, 24, 998-1004. [CrossRef]

64. Malmström, H.; Vilà, C.; Gilbert, M.T.P.; Storå, J.; Willerslev, E.; Holmlund, G.; Götherström, A. Barking up the wrong tree: Modern northern European dogs fail to explain their origin. BMC Evol. Biol. 2008, 8, 71. [CrossRef]

65. Benson, D.A.; Cavanaugh, M.; Clark, K.; Karsch-Mizrachi, I.; Lipman, D.J.; Ostell, J.; Sayers, E.W. GenBank. Nucleic Acids Res. 2013, 41, D36-D42. [CrossRef]

66. Loog, L.; Thalmann, O.; Sinding, M.-H.S.; Schuenemann, V.J.; Perri, A.; Germonpré, M.; Bocherens, H.; Witt, K.E.; Samaniego Castruita, J.A.; Velasco, M.S.; et al. Ancient DNA suggests modern wolves trace their origin to a Late Pleistocene expansion from Beringia. Mol. Ecol. 2020, 29, 1596-1610. [CrossRef]

67. Ameen, C.; Feuerborn, T.R.; Brown, S.K.; Linderholm, A.; Hulme-Beaman, A.; Lebrasseur, O.; Sinding, M.-H.S.; Lounsberry, Z.T.; Lin, A.T.; Appelt, M.; et al. Specialized sledge dogs accompanied Inuit dispersal across the North American Arctic. Proc. R. Soc. B Biol. Sci. 2019, 286, 20191929. [CrossRef]

68. Savolainen, P.; Zhang, Y.; Luo, J.; Lundeberg, J.; Leitner, T. Genetic Evidence for an East Asian Origin of Domestic Dogs. Science 2002, 298, 1610-1613. [CrossRef]

69. Leonard, J.A.; Wayne, R.K.; Wheeler, J.; Valadez, R.; Guillén, S.; Vila, C. Ancient DNA evidence for Old World origin of New World dogs. Science 2002, 298, 1613-1616. [CrossRef] [PubMed]

70. Ardalan, A.; Kluetsch, C.F.; Zhang, A.; Erdogan, M.; Uhlén, M.; Houshmand, M.; Tepeli, C.; Ashtiani, S.R.M.; Savolainen, P. Comprehensive study of mtDNA among Southwest Asian dogs contradicts independent domestication of wolf, but implies dog-wolf hybridization. Ecol. Evol. 2011, 1, 373-385. [CrossRef] [PubMed]

71. Muñoz-Fuentes, V.; Darimont, C.T.; Paquet, P.C.; Leonard, J.A. The genetic legacy of extirpation and re-colonization in Vancouver Island wolves. Conserv. Genet. 2010, 11, 547-556. [CrossRef] 
72. Okumura, N.; Ishiguro, N.; Nakano, M.; Matsui, A.; Sahara, M. Intra- and interbreed genetic variations of mitochondrial DNA major non-coding regions in Japanese native dog breeds [Canis familiaris). Anim. Genet. 1996, 27, 397-405. [CrossRef] [PubMed]

73. Tsuda, K.; Kikkawa, Y.; Yonekawa, H.; Tanabe, Y. Extensive interbreeding occurred among multiple matriarchal ancestors during the domestication of dogs: Evidence from inter- and intraspecies polymorphisms in the D-loop region of mitochondrial DNA between dogs and wolves. Genes Genet. Syst. 1997, 72, 229-238. [CrossRef]

74. Castroviejo-Fisher, S.; Skoglund, P.; Valadez, R.; Vilà, C.; Leonard, J.A. Vanishing native American dog lineages. BMC Evol. Biol. 2011, 11, 73. [CrossRef]

75. Oskarsson, M.C.R.; Klütsch, C.F.C.; Boonyaprakob, U.; Wilton, A.; Tanabe, Y.; Savolainen, P. Mitochondrial DNA data indicate an introduction through Mainland Southeast Asia for Australian dingoes and Polynesian domestic dogs. Proc. R. Soc. B Biol. Sci. 2012, 279, 967-974. [CrossRef]

76. Angleby, H.; Savolainen, P. Forensic informativity of domestic dog mtDNA control region sequences. Forensic Sci. Int. 2005, 154, 99-110. [CrossRef]

77. Rozas, J.; Librado, P. DnaSP v5: A software for comprehensive analysis of DNA polymorphism data. Bioinformatics 2009, 25, 1451-1452. [CrossRef]

78. Fluxus-Engineering.com. Available online: https://fluxus-engineering.com/ (accessed on 25 October 2020).

79. Bandelt, H.-J.; Forster, P.; Röhl, A. Median-joining networks for inferring intraspecific phylogenies. Mol. Biol. Evol. 1999, 16, 37-48. [CrossRef]

80. Huelsenbeck, J.P.; Ronquist, F. MRBAYES: Bayesian inference of phylogenetic trees. Bioinformatics 2001, 17, 754-755. [CrossRef] [PubMed]

81. Pires, A.E.; Detry, C.; Fernandez-Rodriguez, C.; Valenzuela-Lamas, S.; Arruda, A.M.; De Grossi Mazzorin, J.; Ollivier, M.; Hänni, C.; Simões, F.; Ginja, C. Roman dogs from the Iberian Peninsula and the Maghreb-A glimpse into their morphology and genetics. Quat. Int. 2018, 471, 132-146. [CrossRef]

82. Marinov, M.; Teofanova, D.; Gadjev, D.; Radoslavov, G.; Hristov, P. Mitochondrial diversity of Bulgarian native dogs suggests dual phylogenetic origin. PeerJ 2018, 6, e5060. [CrossRef] [PubMed]

83. Zhilin, M.G.; Savchenko, S.N.; Schmölcke, U.; Nikulina, E.A.; Hartz, S.; Terberger, T. Eleven bone arrowheads and a dog coprolite-The Mesolithic site of Beregovaya 2, Urals region (Russia). Quartär 2014, 61, 165-187. [CrossRef]

Publisher's Note: MDPI stays neutral with regard to jurisdictional claims in published maps and institutional affiliations.

(C) 2020 by the authors. Licensee MDPI, Basel, Switzerland. This article is an open access article distributed under the terms and conditions of the Creative Commons Attribution (CC BY) license (http://creativecommons.org/licenses/by/4.0/). 